\title{
Mediated religion: Implications for religious authority
}

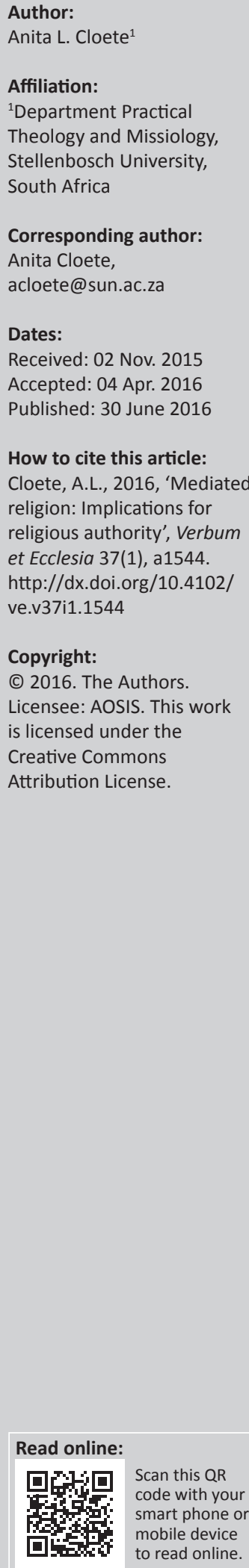

The relationship between media and religion seems to be a well established research topic today. Themes like identity formation and community with regard to digital religion are well researched, but religious authority is pointed out as an area that needs more detailed investigation. Although the topic of authority has been of interest to scholars and practitioners, religious authority received less attention and systematic analysis. Therefore, this article considers the interplay between media and religion by highlighting the possible implications for religious authority when religion is mediated specifically through technology. To illustrate the possible implications for religious authority in a context where religion is mediated through technology, this article will identify certain shifts that took place with regard to religion. In the light of the identified changes with regard to religion, the article will attempt to specifically explore and identify the possible implications for religious authority. At least two theoretical perspectives used to investigate and understand the relationship between technology and theology will be mentioned, namely the instrumentalist and the cultural approach. The mediatisation theory will be discussed as a theory that fits within the cultural approach to media and religion. Furthermore, the mediatisation theory will serve as a theoretical lens to provide insight into how the changes and shifts discussed are changing religion and religious authority.

Intradisciplinary and/or interdisciplinary implications: The article draws on literature from cultural, media and religious studies and intends to stimulate and challenge theological reflection on the theme of mediatisation of religion and the implications for religious authority. Furthermore the article contributes to interdisciplinary research within theology.

\section{Introduction}

Our everyday living is increasingly characterised by the use of technology in almost every sphere of life. In the words of Van der Laan (2012:242) '... we rely (faith) and use (need) technology in every sphere of life: from agriculture, energy, medicine, telecommunication, transport to business, education, finance, politics and psychology'. It is therefore safe to argue that the use of technology is embedded in our everyday living. Moreover, technology became part of the fabric of social consciousness and not just an influence on that consciousness (Hoover 2006:35). As the use of the internet increasingly becomes part of the everyday life of people, there also seems to be greater integration of online- and offline-life as people seamlessly switch from face-to-face interaction to the internet (Lundby 2012:37).

In this article religion is understood to be embedded in social and cultural life, and therefore also the associated authority thereof. Religious authority seems to be ascribed to rituals and people through the complex social process of religion as social phenomenon. As the social and cultural practices and context changes, the socially constructed process of religion and religious authority are affected by these changes. It further implies that religion to a great extent is a product and reflection of the current cultural trends. Although these kind of cultural changes take place all the time, the impact of the new media forms is significantly bigger because of its direct effect of their applications and the widespread changes made possible (Horsfield \& Teusner 2007:284). Theological reflection on how religion is reconstructed through cultural changes is often neglected (Horsfield 2003:272) and therefore this article hopes to make a contribution in this area.

Several researchers noted the need for research on the impact of mediated religion on religious authority (Campbell 2007:1043; Kong 2001:407; Lynch 2011:206; Woodhead 2011:134) (Cheong 2013:72). Therefore, the overall aim of the article is to make a contribution in this regard. The first part of the article will pay attention to mediated religion, followed by a concise description of religious authority. As part of a reflection on theoretical paradigms used to study the relationship between 
religion and media, the mediatisation theory will be discussed in more detail. The mediatisation theory provides a plausible framework to understand how religious authority, of especially institutionalised religion, is affected by mediation of religion through technology. The last section identifies certain changes that are taking place with regard to religion in the context where religion is mediated by the media. In light of these identified changes, the implications for religious authority will be outlined.

\section{Mediated religion}

Religion could be understood to be always mediated by cultural means and is therefore always mediated. Horsfield (2003:279-280) explains, for example, how Christianity was mediated by the spoken word, and then through Jesus' words and actions, and later by the written word as the sacred text. This cultural embeddedness of religion makes it accessible and meaningful to members. Lundby (2013:226) succinctly describes the interrelatedness between religion and the medium in which it is communicated by stating that: "The forms of mediation should be regarded as an integral part of the definition of religion'. Throughout history religion has been translated for new generations in a new context. Religion could therefore not be analysed outside the forms and practices of mediation that defines it. It could therefore be argued that religion should be understood in terms of the modes by which it is communicated. Putting it differently, religion is to a great extent shaped by the forms and practices by which it is mediated. It is therefore paramount to investigate the transition from one medium to another and how it contributes to the reconfiguration of religious practice. Horsfield (2012:246) refers to Ongs' (1982) characteristics of media that change the construction and communication of human reality; the senses that are being addressed and activated, how information is stored, retrieved and reproduced and the organisation of social relationship and social organisational structures. All these areas are also closely linked to religion, because religion is embedded in the cultural practices of the day. In the following section I would like to give a snapshot of the most common concepts that describes the development of the relationship between religion and digital media. Furthermore, these concepts are also an attempt to describe how religion is mediated through technology.

Digital religion includes religion online and online religion. Religion online provides online information about religion whilst online religion provides opportunity to participate in a religious activity (Young 2004:93). It is not clear when religion online becomes online religion as it depends on what the users make of the experience and what it means to them. For example, a prayer request could be seen as both online religion (information), but also religion online as it creates the opportunity for others to respond to that request online and then that request becomes a spiritual experience for many online. It is important to take note that digital religion is different from other forms of religion because it is wrapped in a particular form of media. The characteristics of digital religion of interactivity and hypertextuality differentiate it from analogue religion. Furthermore, digital religion is part of a 'technological ideology' and reflects the connections of technology to economics, politics and culture (Grieve 2013:108). 'A technological ideology represents the beliefs and logic systems that support a given technology'. The technological ideology and therefore digital religion are tied to revolutionary practices, the triumph of human creativity and freedom over dogma and blind tradition. Therefore, digital religion is more than just a new medium and form of communication and represents a new vision for society and engages with revolutionary practices. Noteworthy is the fact that digital religion assists people to cope with ambiguity and uncertainty in a fast changing world (Grieve 2013:109).

The availability of religious and theological information from a variety of sources online (religion online) implies that the traditional structure of the church as the primary source for religious and theological information and authority is bypassed. Similarly authentic figures like pastors are no longer viewed as the only authorities with regard to religious and theological information. In the words of Cheong (2013:75) '... the Internet challenges authority by expanding access to religious information in a way that undermines the plausibility structure of a religious system'. Online religion includes participation in rituals as an integral part of religion in general and is based on a vertical conception of control, status and authority and has the idea of unstructured open and non-hierarchical interaction (Hoover \& Park 2004:122). The authenticity of the ritual and the experience is however questioned. Does someone need to religiously qualify to host an online ritual? Is bodily presence not necessary in order for a ritual to be real and authentic? Who decides on the authenticity of this online ritual? Although religion online bypasses the traditional institutional structures of religion and questions the authenticity thereof, it seems to be real for those participating. Digital religion therefore confirms the value of rituals for meaning making in people's lives.

\section{Religious authority}

Chados (2012:262) points out two very important meanings or dimensions of authority, namely social authority (it comes with a certain social position like a pope, judge) and inner authority that is associated with what is seen or experienced as authenticity. Campbell (2007) argues that in order to investigate religious authority online, a multilayered understanding of authority is of importance. After a study that she conducted with different religious traditions on religious authority online, namely Christianity, Islam and Judaism, she introduces four layers of authority. These layers include religious hierarchy (roles and perceptions about religious leaders), religious structures (systems of community practice organisation), religious ideology (faith beliefs or shared identity) and text (recognised teachings from official religious books).

In similar fashion Linda Woodhead (2011) introduces a broader understanding of religion by identifying five aspects thereof, namely religion as culture, identity, 
relationship, practice and power. According to this multifaceted understanding of religion, power seems to be an integral part thereof that has been neglected, according to Woodhead (2011:134). According to her description of religion as power, power lies at the heart of religion, which typically offers relationships with some form of higher power or powers. Woodhead (2011) stated:

Religion indicates where power really lies (in forces of good or evil) and allows people to enter into this relationship, by understanding it, worshipping it, drawing upon it, manipulating it, railing against it, mediating upon it, making offerings to it and falling in love with it. (p. 134)

Chados (2012:261) extends the idea that religion has always been affiliated with authority by stating that religion is dependent on, even reinforced by the prevalent political and social authority structure. Under religion as power, Woodhead (2011:134-137) lists religion as compensator and capital, religious resources, economic and political power, status and recognition. From this description of Woodhead (2011) it became clear that religion is much broader and complex than what is often reckoned with in research even in research. In light thereof he suggests that religion should be understood through its practices performed through cultural works performed by its adherents. Ganzevoort (2009) concurs with a broader understanding of religion and defines it as '... the transcending patterns of action and meaning, emerging from and contributing to the relation with the sacred'. Therefore religious authority could also be understood in relational terms between realities that manifest and acknowledge the authority (Cheong 2013:73).

In the foregoing discussion it became clear that religious authority is intertwined with how and what is regarded as religion. Furthermore, religious authority is located in people like pastors, ritual, myths, and sacred text and experienced by people in relation to the sacred. This broader understanding of religion also signals a shift in religious authority as will become clearer in the latter part of the article. In other words a change in the understanding of religion has a direct bearing on how and where its authority lies.

\section{Theoretical perspectives on religion and media}

Although different perspectives on studying media and religion exist, I would like to point out at least two basic strands of theoretical frameworks that guide the study of religion and media. The first one is the instrumentalist approach (Horsfield 2004:24), according to which religious institutions see the media as liberator to free the world and through which they can expand and intensify their mission. Theinstrumentalistapproach represents a linear understanding of technology as a simple tool that is value neutral and could therefore be used as the user found fit (Campbell 2012:82).

The second perspective is more complex and comprehensive, as it acknowledges the media as a culturally embedded institution like religion (Horsfield \& Teusner 2007:279).
The change from an instrumentalists' approach to a cultural approach has major implications for media research and religious institutions. As technology advances the instrumentalist approach to studying media becomes insufficient and therefore new metaphors and theoretical frameworks were needed to engage with the complexity of the medium and the effect thereof. This leads to the move from viewing the media as instrumental to a web of culture upon which all the other cultural activities and institutions are located and constructed (Horsfield 2003:275). It signifies a shift away from viewing religious institutions as the primary definers and guardians of religious reality, to where religious institutions are recognised as one amongst other culture institutions (Horsfield 2004:23-25). According to the cultural approach the media should be viewed as a constitutive factor in theology, though not just a functional one.

The mediatisation theory could be helpful to understand the media as a cultural embedded institution that mediates communication, provides opportunity for meaning making, as well as the contextual and ambiguous nature thereof. The mediatisation theory specifically reflects on the relationship between media and institutions and highlights the implications for institutionalised religion. The mediatisation theory postulates that the media is seen as part of society and therefore at work in all types of institutions (Hjarvard 2011:121). Moreover the media has developed into an autonomous independent institution in society and is at the same time being integrated into the workings of other social institutions. The independence and autonomy of the digital media implies that it is no longer in service of other institutions, but now has a logic of its own to which social institutions have to comply. This implies that the media has power over institutions to adhere to its own logic. In this process the authority of institutions is affected and could even be compromised. This is done through the agendasetting function of the media. Through filtering the media set the agenda by deciding on what to report on and how to report on it (Soukup, Buckley \& Robinson 2001:368). The agenda-setting function of the media implies that the media acquires some of the church's former power to define and frame religious issues (Hjarvard 2011:125-126). Although the media make use of religious symbols, the media do not do so with the intension of propagating a specific religious view (Hjarvard 2011:126). This alludes to the weakening power of the religious institutions to control the meaning of their religious symbols or to resist media critique and the opportunities for banal religion through the mediated circulation of religious symbols (Lynch 2011:205). In one of his latest articles Hjarvard (2016) argues specifically that mediatisation leads to the changing of religious authority. Hjarvard (2016:2) explains that the change of religious authority through the complex process of mediatisation does not happen in a linear way. This change is brought about by dual processes and paradox, because religious beliefs and practices could be contested and reasserted, destabilised and enabled by the media. He cautions, however, that the increasing visibility of religion through different vehicles of the media does not imply that the media becomes religious, 
but that religious practices and functions '... may be transformed and re-contextualized in more secular domains' (Hjarvard 2016:4). It implies further that the ties between religious symbols and discourses and religious communities and institutions are loosened as they are recontextualised in a more secular context (Hjarvard 2016:5). In this context where religious symbols and practices are disembedded from religious institutions and communities authority seems to be relocated to individuals and collective practices becomes also a token of authority (Hjarvard 2016:7).

There is a valuable critique against the mediatisation theory that in my view could even contribute to a better understanding of what the theory entails. Lovheim (2011:154) notes that the mediatisation theory operates with a limited understanding of religion as cognitive phenomena and mediation as a single act of communication, therefore losing sight of the reciprocal nature of communication. According to Lynch (2011), the theory is more applicable to highly modernised societies, it is very contextual, historical and culturally specific and therefore does not provide an adequate framework to think about religion and media and social change in general. Despite the valuable critique against this mediatisation theory by scholars like Lovheim (2011) and Lynch (2011), I still find it a useful theoretical framework for research on religion and media. The mediatisation theory helps researchers to understand media as a culture form that exists alongside other culture forms like religion and religious institutions. Furthermore, it highlights the ability of the media to use religion and create religious experiences through secular symbols and narratives. It resists a linear understanding of the effect of media, but is open to diversity and ambiguity and could guide researchers to an open-ended process of research that could come to different conclusions in different contexts.

There seems to be a blurring of the secular and the sacred as already pointed out by the mediatisation theory. The media used sacred religious symbols for its own purposes and not with the motive to advance any specific religion or use secular symbols and narratives to create a religious experience. Furthermore, what is understood as religion, is also under the spotlight and therefore in need of reconsideration and reformulation. A few changes regarding religion will be introduced that could be connected to religion being mediated by technology, followed by the possible implications for religious authority.

\section{Changes that took place with regard to religion and implications for religious authority}

There seems to be a move from institutionalised religiosity to individual spirituality. According to Hoover (2003:11), one of the most important trends in religion is personal autonomy in matters of faith. The numerous opportunities for expression and participation, as well as the aesthetical and experiential character of the media, make it a desirable space to work out the spiritual quest of the spiritual self (Hoover 2003:13). Religion is seen as a project of the autonomous reflexive self. This process is also referred to as seeking or questing and includes the rearticulation or restructuring of religion from the broader market place than traditional religious institutions. Pninit and Ofra (2014:38) also argue that the open, autonomous and individual nature of spirituality may be considered as the most adaptive for identity in today's changing world. In such a context the people may see and describe themselves as spiritual, but not religious, because personal experience is valued more than institutional sources of authority (Pninit \& Ofra 2014:20). Religion is therefore understood more in terms of personal experience than cognitive knowledge often associated with religious institutions.

This individualised spirituality leads to a decline in institutional authority and a rise in personal autonomy through almost disorderly individual freedom. In a context where being religious takes on a more personal quest, it could imply a loss of communal faith grammar for collective meaning making. Furthermore personal or individual spirituality does not necessitate belonging in the traditional sense, but implies rather a move towards longing or seeking by the individual from a wide variety of sources, other than traditional religious institutions only (Hoover 2006:53). Authority therefore seems to be rather coming from the bottom up (the individual and everyday life experiences) than from the top down (religious institutions). Chados (2012:262), however, has a different view with regard to the individual power and authority made possible by the digital media. He argues that it means that authority is now linked to popularity (social authority) and not authentic (inner authority). He further associates the availability of especially information on the internet as leading to the loss of mystery. He describes it in almost direct opposite terms than Hoover, as a shift from seeking to searching. Searching means that we look for what we already have or know, but seeking on the other hand means we are not sure what we are looking for or even of it could be found (Chados 2012:264).

This contemporary spirituality is not derived from one single faith tradition, but rather from a range of different faith traditions which the individual found meaningful and attractive. Versteeg and Roeland (2011:120) describe the subjective nature of spirituality as characterised by the turn to experience. Individuals compile their individual religion out of bits and pieces from different religions. Digital religion offers a 'market place' where individuals may pick and mix their religious identity (Zaleski 1997). Therefore, the metaphor of a pilgrim does not really fit spiritual formation, but rather a wanderer that is at home anywhere and nowhere (Cloete 2012). Belonging to a specific religious institution that ascribes to a specific faith tradition, could become problematic in such processes of spirituality, which could have a direct bearing for instance on membership of local religious institutions. Ganzevoort (2012) claims religious institutions did not only lose their authoritative position, but also their representative power. 
The digital media provide a diversity of voices, opinions and information on life and religion specifically. Therefore being religious or spiritual is characterised by a move from clear doctrines to where ambiguity is embraced. Put differently, religion is not necessarily leading to homogeneity, but to diversity. Diversity therefore becomes more attractive and even more pragmatic than homogeneity. Part of the diversity provided by the digital media is also counter movement to the traditional institutions and authorities where it is questioned and even criticised. The diversification of religious traditions and perspectives is also defined as a process of pluralisation, which in turn makes defining the religious landscape extremely difficult. Pninit and Ofra (2014) make the following conclusion after a study on spiritual identity outside institutionalised religion:

Our findings also suggest that the ability to obtain and maintain this form of postmodern identity that is dialectic, fluid, and simultaneously stable and coherent, relies on spirituality as a unifying mechanism and a reflective self-examination that enables contradiction. (p. 38)

The effect of postmodernism is described as opening up new possibilities for multiple identities and beliefs and at the same time destabilises central values and narratives. Therefore there is a move from rootedness to fluidness or, put differently, rootedness lies in the fluidness. This fluid process seems to be dependent on constant change and innovation. This means the focus is not so much on consolidating the old and known, but rather on seeking and incorporating the new and unknown.

One of the characteristics of the new digital media is that interactivity is possible on different levels. It means that people have different opportunities to opinion formation through different platforms created by social media. Therefore, a move from passive users to active participants is possible as producers and interpreters of content. This interactivity is described as the democratisation of religion as in the hands of the people. Authority therefore shifts from institutions to the media audience (Horsfield 2012:255). This further implies a move from controlled messages to negotiated meaning-making processes by users as coproducers and interpreters of media. Horsfield (2003:281) argues that the crisis in institutionalised religion is a crisis of meaning. Meaning making on the other hand is central to religion (Woodhead 2011:123) and it is this area that digital media seems to zoom in on. Through music, video games and films, for instance, meaning making takes place differently than before as it places meaning making in the hands of the individual and not in the message itself. Films introduce the sacred in the secular in everyday life and are a good example of how spirituality is about our everyday life and a sought after agent of meaning making. In that sense popular culture in some instances replaces the role of religious institutions and text as traditional agents of meaning making.

Horsfield and Teusner (2007:292) argue that a valid and more important question than where religious authority lies, is rather on how and who is doing theology today.
'Throughout the modern period, authority in religious matters was strongly institutional in its ascription' (Horsfield 2012:255). Digital media however have significantly undermined this institutional structure and subverted religious authority in the process. Theological knowledge is therefore no longer situated in a few that have the privilege to study and learn a sophisticated and philosophical grammar, but what is authoritative has shifted from social intuitions to media audiences. Horsfield (2012:257) suggests that a theology that is influential in the media age should be more fluid and flexible and should rather have the characteristic of oral theology than written theology. Moreover an influential theology in the digital age should be open to audience participation and contributions.

\section{Conclusion}

It is safe to argue that institutional religion will stay relevant, but not in the same fashion as in the past and definitely not as the only institution that can provide religious experience and meaning making. Hjarvard (2016:8) contends that mediatisation of religion by the media contributes to secularisation which does not mean that religion disappears, but that it redefines religion and religious authority. Digital religion confirms the need for religion, rituals and myths as an integral part of being human and therefore I do not think it undermines religion as such. Although some scholars describe the changing context of religion as deinstitutionalised (Heelas \& Woodhead 2005), I am in agreement with Horsfield (2003:272) that religion is not deinstitutionalised, but rather reinstitutionalised through the media. That is because people use their religious ideals and values in the process of meaning making and reinterpret them. The individualistic spirituality, however, rearticulates or restructures religion away from history and religious institutions to where individual practices become more definitive (Hoover 2003:12). Religion however proves to be an active and creative agent, with the ability to actively reshape itself in a changing society. I would therefore argue that religion is not weakened, but transformed as people find new ways of expressing their relationship with the sacred in everyday life. It seems that the song has changed from give me that old time religion to give me that online religion, but definitely not, to no religion.

However the shifts discussed in the last section of the article indicate that mediated religion brought about a move towards individualised spirituality which is compiled from a variety of religious sources. The media became one of the most important sources of religious information and contemporary spirituality. Furthermore a broader understanding of what constitutes religion is needed today as people value experience more than cognitive knowledge about a certain religious tradition. Versteeg and Roeland (2011:131) however cautions that even in a context that is fluid and temporal there are processes of authorisation of practices and ideas. They argued that it is in fact that authoritative interpretation and supervision that makes continuity of fluid religiosity possible. They therefore suggest that 'more questions needs to be asked about how people 
learn to internalise contextually authentic expressions in religious forms that have little or no institutional backup' (Versteeg \& Roeland 2011:132).

\section{Acknowledgements Competing interests}

The author declares that she has no financial or personal relationships which may have inappropriately influenced her in writing this article.

\section{References}

Campbell, H., 2007, 'Who's got the power? Religious authority and the internet', Journal of Computer- Mediated Communication 12, 1043-1062. http://dx.doi. org/10.1111/j.1083-6101.2007.00362.x

Campbell, H., 2012, 'How religious communities negotiate new media religiously', in P.H. Cheong, P. Fischer- Nielsen, S. Gelfgren \& C. Ess (eds.), Digital religion, socia media and culture: Perspectives, practices and futures, pp. 81-96, Peter Lang Publishing Inc, New York.

Chados, R., 2012, 'Reflections on the impact of "The digital revolution" on art and religion', Association for Religion and Intellectual life 62(2), 260-269.

Cheong, P.H., 2013, 'Authority', in H. Campbell (ed.), Digital religion: Understanding religious practice in new media worlds, pp. 72-87, Routledge, New York.

Cloete, A., 2012, 'Spiritual formation as focus of youth ministry', Nederduitse Gereformeerde Teologiese Tydskrif (NGTT) 53(3\&4), 71-77.

Ganzevoort, R.R., 2009, 'Forks in the road when tracing the sacred. Practical theology as hermeneutics of lived religion', Paper presented at the International Academy of Practical Theology, 2009, Chicago, IL.

Ganzevoort, R.R., 2012, 'Framing the Gods: The public significance of religion from a cultural point of view', in H-G. Ziebertz (ed.), The public significance of religion, pp. 95-120, Brill, Leiden.

Grieve, G.P., 2013, 'Religion', in H. Campbell (ed.), Digital religion: Understanding religious practice in new media worlds, pp. 104-118, Routledge, New York.

Heelas, P. \& Woodhead L., 2005, The spiritual revolution. Why religion is giving way to spirituality, Blackwell, Oxford.

Hjarvard, S., 2011, 'The mediatization of religion: Theorizing religion, media and social change', Culture and Religion: An Interdisciplinary Journal 12(2), 119-135. http:// dx.doi.org/10.1080/14755610.2011.579719

Hjarvard, S., 2016, 'Mediatization and the changing authority of religion', Media, Culture and Society 38(1), 8-17.

Hoover, S.T., 2003, 'Religion, media and identity: Theory and method in audience research on religion and media', in J. Mitchell \& S. Marriage (eds.), Mediated Religion: Conversations in media, religion and culture, pp. 9-19, T\&T Clark, London.

Hoover, S., 2006, Religion in the media age, Routledge, Abingdon.
Hoover, S.M. \& Park, J., 2004, 'Religion and meaning in the Digital age: Field research oninternet/webreligion', in J Mitchell \& S. Marriage (eds.) Mediated Religion: Conversations in media, religion and culture, pp. 121-136, T\&T Clark, London.

Horsfield, P., 2003, 'Electronic media and the past-future of Christianity', in J. Micthell \& S. Marriage (eds.), Mediating religion: Conversations in media, religion and culture, pp. 271-282, T \& T Clark, Ltd, London.

Horsfield, P., 2004, 'Theology, church and media- Contours in a changing cultural terrain', in P. Horsfield, M.E. Hess \& A.M. Medrano (eds.), Belief in media: cultural perspectives on media and Christianity, pp. 23-32, Ashgate, Burlington.

Horsfield, P.G., 2007, 'A mediated religion: Historical perspectives on Christianity and the internet', Studies in World Christianity 13(3), 278-295. http://dx.doi.org/ 10.3366/swc.2007.13.3.278

Horsfield, P., 2012, “'A moderate diversity of books?” The challenge of new media to the practice of Christian theology', in P.H. Cheong, P. Fischer-Nielsen, S. Gelfgren \& C. Ess (eds.), Digital religion, social media and culture: Perspectives, practices and futures, pp. 243-258, Peter Lang Publishing house, New York.

Horsfield, P. \& Teusner, P., 2007, 'A mediated religion: Historical perspectives of Christianity and the internet', Studies in World Christianity, 13(3) 278-294.

Kong, L., 2001, 'Religion and technology: Refiguring place, space, identity and community', Religion and Technology 33(4), 404-413. http://dx.doi.org/10.1111/ 1475-4762.00046

Lovheim, M., 2011, 'Mediatisation of religion: A critical appraisal', Culture and Religion (12)2, 155-166. http://dx.doi.org/10.1080/14755610.2011.579738

Lundby, K., 2012, 'Dreams of church in cyberspace', in P.H. Cheong, P. Fischer- Nielsen, S. Gelfgren \& C. Ess (eds.), Digital religion, social media and culture: Perspectives, practices and futures, pp. 25-38, Peter Lang Publishing Inc, New York.

Lundby, K., 2013, 'Theoretical frameworks for approaching religion and new media', in H. Campbell (ed.), Digital religion: Understanding religious practice in new media worlds, pp. 225-237, Routledge, London.

Lynch, G., 2011, 'What can we learn from the mediatisation of religion debate', Culture and Religion (12)2, 203-2010. http://dx.doi.org/10.1080/14755610.2011.579714

Ong, W.J., 1982, Orality and Literacy: The technologizing of the world, Routledge, London.

Pninit, R. \& Ofra. M., 2014, 'Spiritual identity outside institutional religion: A phonological exploration', International Journal of Theory and Research 14(1), 10-42.

Soukup, P.A., Buckley. F.J. \& Robinson, D.C., 2001, 'The influence of information technologies on theology', Theological Studies 62, 366-377. http://dx.doi.org/ $10.1177 / 004056390106200207$

Van der Laan, J.M., 2012, 'Language and being human in technology', Bulletin for Science, Technology \&Society 32(3), 241-252. http://dx.doi.org/10.1177/ 0270467612458092

Versteeg, P. \& Roeland, J., 2011, 'Contemporary spirituality and the making of religious experience: Studying the social in an individualized religiosity', Fieldwork in Religion 6(2) http://dx.doi.org/10.1558/fiel.v6i2.120

Woodhead, L., 2011, 'Five concepts of religion', International review of Sociology 21(1), 121-143. http://dx.doi.org/10.1080/03906701.2011.544192

Young, G., 2004, 'Reading and praying online: The continuity of religion online and online religion in internet Christianity', in L.L. Dawson \& D.E. Cowan (eds.) Religion online: finding faith on the internet, pp. 93-95. Routledge, London.

Zaleski, J., 1997, The soul of cyberspace: How new technology is changing our spiritual lives, Haper Collins, New York. 